\title{
Distribution and Classification of Marine Bacteria with the Ability of Cytokinin and Auxin Production
}

\author{
Akihiko Maruyama ${ }^{2}$, Masachika Maeda ${ }^{1}$, and Usio Simidu ${ }^{1}$ \\ ${ }^{1}$ Ocean Research Institute, University of Tokyo, Minamidai, Nakano, Tokyo 164, Japan \\ ${ }^{2}$ Present address : Fermentation Research Institute, Agency of Industrial Science \\ and Technology, Higashi, Tsukuba, Ibaraki 305, Japan
}

\begin{abstract}
Bacterial production of cytokinin-type and auxin-type plant hormones was investigated with 328 strains isolated from seawater, sediment and various alga samples. Proportions of the producers among heterotrophic marine bacteria were quite high, 10-80\%, showing higher rate in the samples from multicellular algae and sediments than those from unicellular algae and seawater. The amount of auxin, indole-3-acetic acid, produced in the culture was mostly in the level of $10^{-7} \mathrm{~mol} / 1$, which was about 100 fold greater than that of cytokinin compounds. Marine Gram-negative bacteria capable of the cytokinin and the auxin production were classified in 9 groups by a combination of key taxonomic characters. In the alga samples, there were some differences in taxonomic groups between cytokinin- and auxin-producers, but as a whole the ability of plant hormone production tended to distribute in various genera of marine bacteria.
\end{abstract}

Key words : Marine bacteria, Plant hormone, Algae

\section{Introduction}

Several hormonal compounds in terrestrial higher plants have been regarded as possible growth regulators in malticellular algae (Lobban, 1985). Although prominent functions of plant hormone in the algal growth and development are not well understood, recent study showed that the algal callus formation was stimulated by the addition of a cytokinin, kinetin and an auxin, indole3-acetic acid (Gusev et al., 1987), suggesting the universal role of these compounds as growth regulators among plant organisms.

Microbial production of plant hormone is well known among terrestrial plant pathogenic micro-organisms, and the virulency of some pathogens to host plants correlates with the ability of plant hormone production (Morris, 1986). In addition, several reports suggest that bacteria which produce cytokinin-like and auxin-like compounds widespread in terrestrial soils (Brown,
1972 ; Barea et al., 1976; Kampert and Strzelczyk, 1984), and the plant hormones derived from rhizosphere micro-organisms seem to affect the plant growth (Brown, 1972; Whipps and Lynch, 1986). In the sea, however, the microbial production of plant hormone has not been well examined, although some reports show that certain microbial products are necessary for the growth of unicellular algae (Provasoli et al., 1957) and also of multicellular algae (Mishra and Kefford, 1969; Harrison, 1978; Provasoli and Pintner, 1980).

In the previous reports, we showed the presence of cytokinin-producing bacteria in the sea for the first time (Maruyama et al., 1986) and clarified chemical structures of the cytokinin-active compounds as isopentenyladenine and isopentenyladenosine and surveyed plasmid-inclusion of the producer (Maruyama et al., 1988). In addition, we detected an auxin indole-3-acetic acid from marine sediments for the first time and demonstrated the microbial origin of this compound in the 
environments (Maruyama et al., 1989). These findings suggest that the plant hormone production may be a general function among most marine bacteria as well as terrestrial ones. In this report, we present further knowledge on the distribution of marine bacteria capable of cytokinin and auxin production using strains isolated from seawater, sediments and multicellular and unicellular algae. The taxonomic characteristics of the producers are also studied to appear difference in habitat of the producers.

\section{Materials and Methods}

\section{Bacterial isolation and culture}

Seawater samples were collected by a Niskin Butterfly-type water sampler from various depths of Stn. P-8 located in the northwest region of Pacific Ocean, $25^{\circ} \mathrm{N} / 135^{\circ} \mathrm{E}$, during the $\mathrm{KH}-85-3$ cruise on board the $\mathrm{R} / \mathrm{V}$ Hakuho-maru (Ocean Research Institute, University of Tokyo) from May to July 1985. Ten to a hundred $\mathrm{ml}$ of sample was filtered with a sterilized Nuclepore filter (pore size : $0.2 \mu \mathrm{m}$ ), and the filter was put on the modified PPES-II agar plate (Maruyama et al., 1986) for bacterial incubation. Sediment samples were obtained using an Phleger-type gravity corer from Tokyo and Sagami Bays during the KT-8510 cruise on board the R/V Tansei-maru (ORI, U. of Tokyo) on July 1985. Upper 0-1 cm layer of the sediments was used for isolating bacteria. Seaweed samples were collected by skin diving in Aburatsubo Inlet in 1985. Each sample was immediately rinsed with sterile seawater and cut with a sterile corkborer of $11.4 \mathrm{~mm}$ in diameter to give five $1 \mathrm{~cm}^{2}$ pieces. These five pieces were rinsed further three times in the $100 \mathrm{ml}$ bottles with sterile seawater and blended by the method of Shiba and Taga (1980) to remove bacteria from the algal body. Bacterial strains were also isolated from non-axenic cultures of unicellular algae in the late logarithmic phase of the growth. The culture had been maintained in a sterilized medium for a year. Sediment and alga samples were seri- ally diluted with sterile seawater and spread on the agar plates for the isolation of bacteria. All bacterial cultures were incubated at $20^{\circ} \mathrm{C}$ for 14 days before colony counting. From the agar plate bacterial isolates were transferred and incubated in the modified PPES-II broth on a rotary shaker at $20^{\circ} \mathrm{C}$. The culture was centrifuged at $11,000 \mathrm{~g}$ for $15 \mathrm{~min}$ at $4^{\circ} \mathrm{C}$, and the culture supernatant was stored at $-20^{\circ} \mathrm{C}$ until use.

\section{Cytokinin bioassay}

Culture supernatant was partially purified through the Sep Pak C 18 column, and the extracted sample was applied to the cytokinin bioassay using cotyledon-hypocotyl parts of Amaranthus caudatus seedlings (Maruyama et al., 1986). In the present study, the residual explant materials after extraction were removed by the centrifugation at $16,000 \mathrm{~g}$ for $5 \mathrm{~min}$. To reduce experimental error, the culture supernatant fluids of all bacterial isolates which were originated from one sample were assayed at the same time, using the culture medium as a blank.

\section{Immunological detection of indole-3-acetic acid (IAA)}

Culture supernatant was partitioned two times against the same volume of diethylether at $\mathrm{pH} 8.5$. The aqueous phase was then adjusted to $\mathrm{pH} 2.5$ 3.0 and partitioned twice more against diethylether. These acidified ether phases were put together and methylesterificated by the addition of ethereal diazomethan which was prepared from $\mathrm{N}$-methyl$\mathrm{N}$-nitroso- $p$-toluenesulfonamide just before the use. After the reaction for 5-10 min, the solution was evapolated under vacuum, and the dried compounds were dissolved in TBS buffer $(25 \mathrm{mM}$ Trizma base, $100 \mathrm{mM} \mathrm{NaCl}, 1 \mathrm{mM} \mathrm{MgCl}_{2} \cdot 6 \mathrm{H}_{2} \mathrm{O}$, $0.1 \% \mathrm{NaN}_{3}, \mathrm{pH} 7.5$ ). IAA concentration in the culture extracts was determined by the enzymelinked immunosolvent assay (ELISA) method using antibody for IAA methylester (Mertens et al., 1985). Polystyrene flat-bottom microtitration plates (Nunc) precoated with rabbit anti-mouse 
immunoglobulin (Miles, Israel) were used. Monoclonal antibody for IAA methylester and alkaline phosphatase-labeled IAA methylester were purchased from Idetek, USA, which were applied to the immunoassay according to the instruction of Idetek. Each sample was assayed in duplicate and the authentic IAA methylester (Fluka) was subjected for caliblation at every assay. The culture sample contained over $3 \times 10^{-8}$ mol IAA per liter was considered to be possitive in IAA production by bacteria, since the IAA content of the medium before use was estimated everytime around $1 \times 10^{-8} \mathrm{M}$.

\section{Bacterial grouping}

Among bacterial strains with the ability of auxin indole-3-acetic acid (IAA) production or cytokinin production, 62 cytokinin producers and 48 IAA producers were used for taxonomic study. Strains were grouped by Gram reaction using both the staining and $\mathrm{KOH}$ methods (Buck, 1982), and then by the mode of glucose catabolism (O-F test) using the marine oxidation-fermentation medium of Leifson (1963). Gram-negative and non fer-

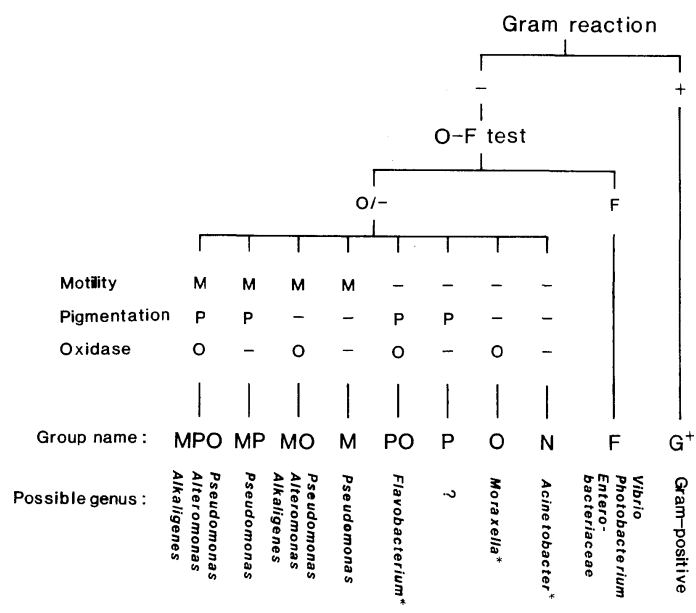

Fig. 1 Taxonomic grouping scheme for marine bacteria. Possible genus was arranged referring to Bergey's Manual of Systematic Bacteriology Vol. I (1984). Asterisk shows a representative genus, although marine species are not described in the manual. mentative bacteria were further classified into 8 groups according to a combination of three taxonomic characters: motility, yellow-orange colony pigmentation and oxidase reaction, as shown in Fig. 1. These key characters were selected by reference to the diagnostic schemes of Shewan et al. (1960 a, b). Group names were expressed as to represent each positive reaction of the three tests, that is, a group PO represents the non-motile, yellow or orange pigmented, and oxidase-positive bacterial group. Based on the Bergey's Manual of Systematic Bacteriology Vol. 1 (1984), almost all genera which contained species known to occurr in marine environments were listed in Fig. 1 corresponding to the present grouping.

\section{Results}

A large proportion of the heterotrophic bacteria present in the seawater and the sediment samples could produce cytokinin-active compounds in the culture condition (Table 1). The proportion of cytokinin-producing bacteria ( $\mathrm{CK}$-producers) among the strains isolated was $20-33 \%$ in the seawater samples from the various depths at Stn. P-8. Higher percentage (44-73\%) of the producers were found in the sediment samples from Tokyo and Sagami Bays. Cytokinin contents in the bacterial cultures were estimated at a few nano mole equivalent of $t$-zeatin per liter.

Many bacterial isolates from seawater and sediments also produced indole-3-acetic acid (IAA). The concentration of IAA in the medium was estimated at $3 \times 10^{-8}$ to over $1 \times 10^{-7} \mathrm{M}$, which were 10 to 100 -fold greater than cytokinins on the molar basis. The proportion of IAA-producing bacteria (IAA-producers) among the isolates from the sea water and the sediment samples was similar to that of $\mathrm{CK}$ producers. IAA-producers in the sediment samples from the two bays were estimated as $40-63 \%$ of the strains tested, while the percentage was $24-40 \%$ in the seawater samples collected from the Stn. P-8 (Table 1).

There was a great difference in the numbers of 
heterotrophic bacteria between the samples of front edges and basal meristems in a brown alga Eisenia bicylis. At all seasons, the heterotrophic bacteria on the front edge samples were a thousand-fold greater than that of the basal meristem samples. On the both samples the proportion of $\mathrm{CK}$-producers ranged $8-83 \%$, and the IAA-producers ranged 28-85\% (Table 2). High percentage of $\mathrm{CK}$-producers was also found in the bacterial strains from a brown alga Ecklonia cava and from a green alga Ulva sp. Orange and yellow pigmented bacteria were apparently predominant among the strains from the green alga compared to those from the other seaweeds. However, few distinct difference in the proportions of $\mathrm{CK}$ - and IAA-producers was seen between samples from the green alga and the others (Table 2). In the bacterial isolates from the culture samples of unicellular algae, $\mathrm{CK}$-producers and IAA-producers were found to be 7-32\% and 30-56 respectively. As a whole, higher frequency of IAA-producers was observed in the isolates from seaweed samples than those from seawater and sediment samples.

Most of the cytokinin-producing bacteria belonged to the groups MPO, MO, PO, and F (Fig. 2). Among them $\mathrm{CK}$-producers of the group $\mathrm{F}$ were dominantly present in the pelagic seawater samples collected at Stn. $\mathrm{P}-8$, while in the sediment and the seaweed samples the groups MPO, MO and PO dominated. IAA-producers also showed wide variation in the taxonomic groups (Fig. 2), as the case of $\mathrm{CK}$-producers. Most IAA-producers belonged to the groups $\mathrm{MO}, \mathrm{PO}, \mathrm{O}$ and $\mathrm{F}$; in the pelagic seawater samples the predominant producers were of the group F, while in the sediment and alga samples the groups $\mathrm{MO}, \mathrm{PO}$ and $\mathrm{O}$ dominated.

In both the seaweed and unicellular alga samples a significant difference in the abundance of the producers was observed between group MPO and O. Considerable number of the IAA-producers in the alga samples belonged to the group $\mathrm{O}$, whereas no $\mathrm{CK}$-producers were seen in the group O. The reverse relationship was seen in group

Table 1. Frequency of occurrence of cytokinin (CK)- and auxin (IAA)-producing bacteria in sewater and sediment samples

\begin{tabular}{|c|c|c|c|c|}
\hline Sample & Viable counts & $\begin{array}{l}\text { No. of strain } \\
\text { examined }\end{array}$ & CK producers & IAA producers \\
\hline $\begin{array}{l}\text { Seawater } \\
\text { Stn. P-8 }\end{array}$ & $(\mathrm{cfu} / 100 \mathrm{ml})$ & & & \\
\hline $0 \mathrm{~m}$ & $1.2 \times 10^{3}$ & 17 & 4 & 4 \\
\hline $100 \mathrm{~m}$ & $1.2 \times 10^{3}$ & 13 & 3 & 5 \\
\hline $300 \mathrm{~m}$ & $4.7 \times 10^{2}$ & 20 & 4 & 8 \\
\hline $1000 \mathrm{~m}$ & $2.8 \times 10$ & 16 & 4 & 5 \\
\hline $3000 \mathrm{~m}$ & $8.1 \times 10$ & 12 & 4 & 3 \\
\hline \multicolumn{3}{|c|}{ Average and range of coccurrence (\%) } & $24(20-33)$ & $32(24-40)$ \\
\hline \multicolumn{3}{|c|}{$\begin{array}{l}\text { Sediment } \quad\left(\mathrm{cfu} / \mathrm{cm}^{3}\right) \\
\text { Tokyo Bay }\end{array}$} & & \\
\hline $\mathrm{T}-2$ & $1.2 \times 10^{6}$ & 15 & 11 & 7 \\
\hline $\mathrm{T}-4$ & $1.8 \times 10^{6}$ & 12 & 6 & 6 \\
\hline $\mathrm{T}-7$ & $7.5 \times 10^{6}$ & 16 & 7 & 10 \\
\hline \multicolumn{5}{|l|}{ Sagami Bay } \\
\hline$S-1$ & $1.1 \times 10^{5}$ & 20 & 9 & 8 \\
\hline \multicolumn{3}{|c|}{ Average and range of occurrence (\%) } & $52(44-73)$ & $49(40-63)$ \\
\hline
\end{tabular}


Distribution and Classification of Marine Bacteria with the Ability of Cytokinin and Auxin Production

Table 2. Frequency of of occurrence of cytokinin (CK)-and auxin (IAA)-producing bacteria in marine alga samples.

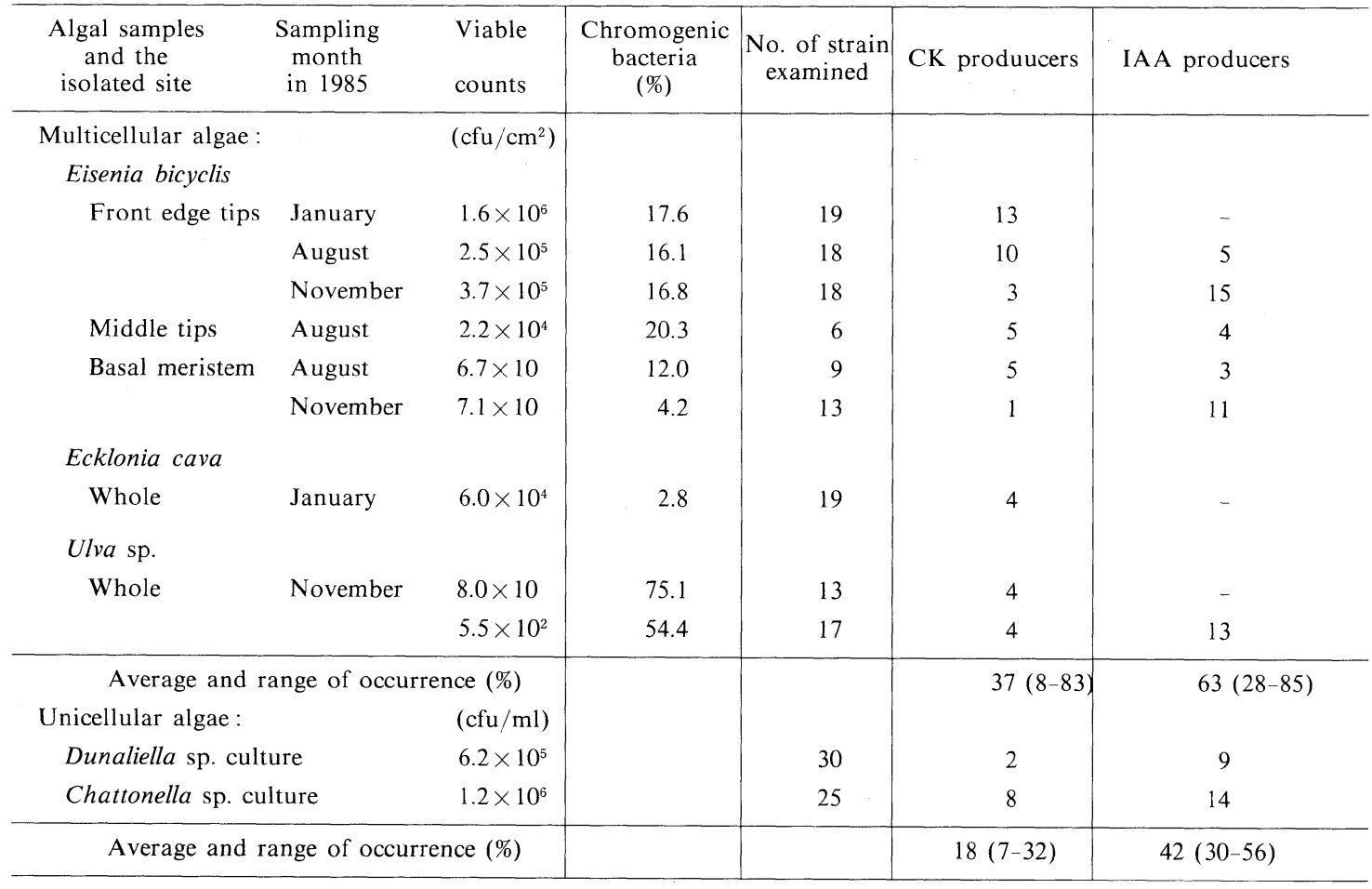

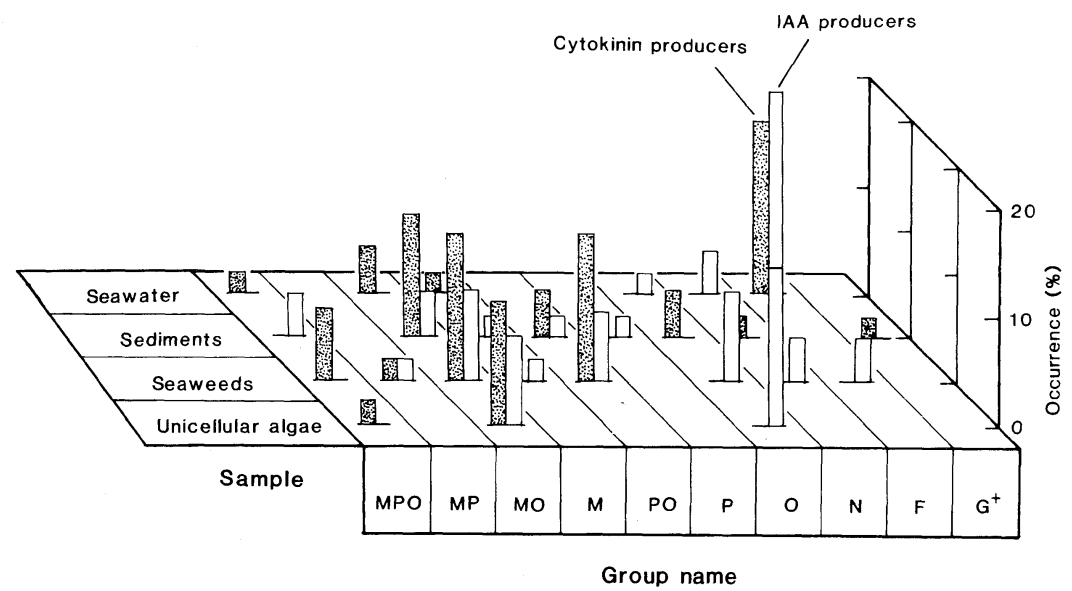

Fig. 2 Taxonomic characteristics of marine bacteria with the ability of cytokinin (CK) and auxin (IAA) production. 
MPO strains; that is, no IAA-producers were found in MPO in contrast to the abundance of CK producers. Although groups of MP, $\mathrm{M}$ and $\mathrm{P}$ showed small percentage among the producers of plant hormones, marine bacteria of various groups as a whole showed to have the ability of producing hormones, and the ability of hormone production did not seem to be restricted to some specific taxonomic groups.

\section{Discussion}

Proportions of the both cytokinin- and auxinproducing bacteria among the heterotrophic bacteria isolated from various marine environments were quite high. All of our data, including the previous one (Maruyama et al., 1986), on the distribution of plant hormone-producing bacteria in the sea were summarized in Fig. 3. Approximately $10-80 \%$ of the culturable marine bacteria produced the plant hormones. There is a significant difference in the occurrence of these producers among the samples from the various origins. High proportions of the auxin- and cytokinin-producers were always found in the sediment samples than the seawater, which may be one of the reasons why high activity of the plant hormone production was found in natural sediments (Maruyama et al., 1989). Although the proportions of the producers in the seaweed samples showed large fructuation, the samples tended to be rich in the auxin-producers than the other samples. Since the bacterial auxin production was evaluated as 10 to 100 fold greater than the cytokinin production in the same culture condition, we assume that auxin IAA of bacterial origin is one of the most possible compounds affecting the algal growth in natural environments, especially around seaweeds.

The prevalent occurrence of cytokinin-producing bacteria was also observed in terrestrial soil, rhizosphere and mycorhizosphere of a pine tree (Kampert and Strzelczyk, 1984). Barea et al. (1976) reported that 45 of 50 bacterial isolates from

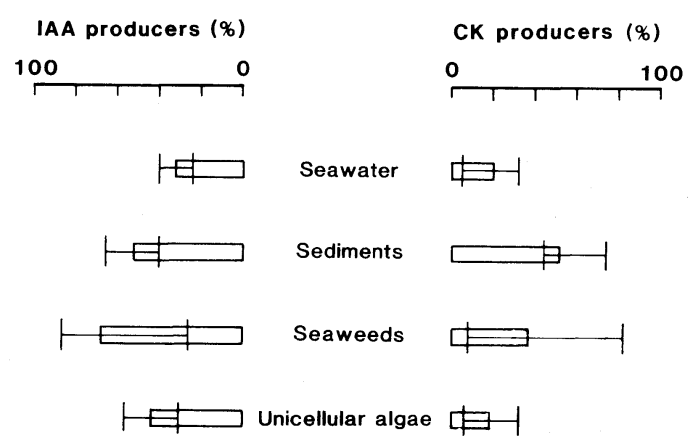

Fig. 3 Average frequency of occurrence of plant hormone-producing bacteria in marine environments. Open bar shows a range of variation.

the rhizospheres of crop plants could produce cytokinin-like compounds and 43 produced auxin-like compounds. The high proportion of auxin (IAA)-producing bacteria, 70-90\% of the isolates, was also reported by Brown (1972) in the samples of rhizospheres and rhizoplanes of wheat plants, and of root-free soil. She pointed out that the similar effects to the growth of wheat seedlings were obtained by the treatments with either gibberelic acid $\left(\mathrm{GA}_{3}\right)$ plus IAA or natural soil inoculum, and assumed that these soil bacteria affected the plant morphogenesis through plant hormones that they produced. Corresponding to these data the present result on marine bacteria suggests that bacterial extracellular production of auxin-type and cytokinin-type plant hormones is a general function among natural microbial communities.

Almost all the bacterial isolates that produced plant hormones belonged to Gram-negative rods. Results of the grouping of the producers of two hormones suggest that they have a wide variety of taxonomic position (Fig. 2). In the pelagic seawater samples the producers were mostly in the group F, including genera Vibrio and Photobacterium, whereas in the sediment and alga samples the producers were mostly found in the groups MO, $\mathrm{PO}$ and $\mathrm{O}$ composing genera such as Pseudomonas Alteromonas, Alcaligenes, Flavobacterium and Moraxella. The Vibrio group, corresponding to the group $\mathrm{F}$ in the present study, is known as one 
of the predominant members in the bacterial flora of the pelagic region (Simidu et al., 1980), whereas in the eutrophic reagion this group is rather rare, and other groups, Pseudomonas group (groups MPO, MP, PO and M) and MoraxellaAcinetobacter group (groups $\mathrm{O}, \mathrm{N}$ ) predominate (Simidu et al., 1977). It is also known that chromogenic bacteria identified as Flavobacterium-Cytophaga group (groups MPO, MP, PO) are often dominant on the green algae, while they are minor in the surrounding seawater (Shiba and Taga, 1980). These suggest that the flora of plant hormone-producing bacteria in the samples reflects the differences in the flora dominating in various environments

Lewis et al. (1985) showed that the Moraxella group (corresponding to the group $\mathrm{O}$ in this work) was autochthonous to the cuticle surface of crustose coralline algae, which comprised $66 \%$ of 732 strains isolated. Shiba and Taga (1980) also pointed out that yellow and orange pigmented bacteria (groups MPO, MP, PO) were predominant in the green algae at all seasons. The predominancy of chromogenic bacteria in green alga samples was also found in the present study. These findings suggest that a characteristic relationship will be present between the algae and their epiphytic bacteria. Although further studies are necessary to elucidate why some specific bacterial groups are predominant on the algal bodies, the present result, that most bacteria associated with algae possess the ability of cytokinin and auxin production, is well consistent to the previous studies that the algal growth and morphogenesis were enhanced by the addition of some plant hormones (Pedersén, 1968, 1973; Mishra and Kefford, 1969 ; Fries, 1984).

\section{Acknowledgements}

We would like to thank Dr. I. Yamaguchi, Faculty of Agriculture, University of Tokyo, for his helpful advice on the immunoassay. Thanks are also due to officers and crew members of the
RV 'Tansei-maru' and 'Hakuho-maru' and the staff of Misaki Marine Biological Station, U. of Tokyo for their assistance in our field works. This research was supported by grants for Scientific Research from the Ministry of Education, Science and Culture, Japan (project no. 62560205).

\section{References}

Barea J.M, E. Navarro and E. Montoya. 1976. Production of plant growth regulators by rhizosphere phosphate-solubilizing bacteria. J. Appl. Bacteriol., 40, 129-134.

Brown, M. E., 1972. Plant growth substances produced by micro-organisms of soil and rhizosphere. J. Appl. Bacteriol., 35, 443-451.

Buck, J.D., 1982. Nonstaining (KOH) method for determination of Gram reactions of marine bacteria. Appl. Environ. Microbiol., 44, 992-993.

Fries, L., 1984. Induction of plantlets in axenically cultivated rhizoids of Fucus spiralis. Can. J. Bot., 62, 1616-1620.

Gusev, M.V., A.H., Tambiev, N.N. Kirikova, N.N. Shelyastina and R.R. Aslanyan, 1987. Callus formation in seven species of agarophyte marine algae. Mar. Biol., 95, 593-597.

Harrison, P.G., 1978. Growth of Ulva fenestrata (Chlorophyta) in microcosms rich in Zostera marina (Anthophyta) detritus. J. Phycol., 14, 100-103.

Kampert, M. and E. Strzelczyk., 1984. Effect of $\mathrm{pH}$ on production of cytokinin-like substances by bacteria isolated from soil, rhizosphere and mycorrhizoshere of pine (Pinus silvestris L.). Acta Microbiol. Polon., 33, 77-85.

Leifson, E., 1963. Determination of carbohydrate metabolism of marine bacteria. J. Bacteriol., 85, 1183-1184.

Lewis, T.E., C.D. Garland and T.A. Mcmeekin., 1985. The bacterial biota on crustose (nonarticulated) coralline algae from Tasmanian waters. Microb. Ecol., 11, 221-230.

Lobban, C.S., 1985. Evidence for internal growth regulators. In: The physiological ecology of seaweeds (edited by C.S. Lobban, P.J. Harrison and M.J. Duncan) pp. 206-208. Cambridge University Press, Cambridge.

Maruyama, A., M. Maeda and U. Simidu., 1986. Occurrence of plant hormone (cytokinin)-producing bacteria in the sea. J. Appl. Bacteriol., 61, 569-574.

Maruyama, A., I. Yamaguchi, M. Maeda and U. 
Simidu., 1988. Evidence of cytokinin production by marine bacterium and its taxonomic characteristics. Can. J. Microbiol., 34, 829-833.

Maruyama, A., M. Maeda and U. Simidu., 1989. Microbial production of auxin indole-3-acetic acid in marine sediments. Mar. Ecol. Prog. Ser., 58, 69-75.

Mertens, R., J. Eberle, A. Arnscheidt, A. Ledebur and E.W. Weiler., 1985. Monoclonal antibodies to plant growth regulators. II. Indole-3-acetic acid. Planta, 166, 389-393.

Mishra, A.K., and N.P. Kefford., 1969. Developmental studies on the coenocytic alga, Caulerpa sertularioides. J. Phycol., 5, 103-109.

Morris, R.O., 1986. Genes specifying auxin and cytokinin biosynthesis in phytopathogens. Ann. Rev. Plant Physiol., 37, 509-538.

Pedersén, M., 1968. Ectocarpus fasciculatus : marine brown alga requiring kinetin. Nature, 218, 776

Pedersén, M., 1973. Identification of a cytokinin, 6(3-methyl-2-butenylamino) purine, in sea water and the effect of cytokinins on brown algae. Physiol. Plant., 28, 101-105.

Provasoli, L., J.J.A. Mclaughlin and M.R. Droop., 1957. The development of artificial media for marine algae. Arc. Mikrobiol., 25, 392-428.

Provasoli, L., and I.J. Pintner., 1980. Bacteria in- duced polymorphism in an axenic laboratory strain of Ulva lactuca (Chlorophyceae). J, Phycol., 16, 196-201.

Shewan, J.M., G. Hobbs and W. Hodgkiss., 1960 a. A determinative scheme for the identification of certain genera of Gram-negative bacteria, with special reference to the Pseudomonadaceae. J. Appl. Bacteriol., 23, 379-390.

Shewan, J.M., G. Hobbs and W. Hodgkiss., 1960 b. The Pseudomonas and Achromobacter groups of bacteria in the spoilage of marine white fish. J., Appl. Bacteriol., 23, 463-468.

Shiba, T., and N. Taga., 1980. Heterotrophic bacteria attached to seaweeds. J. Exp. Mar. Biol. Ecol., 47, 251-258.

Simidu, U., E. Kaneko and N. Taga., 1977. Microbiological studies of Tokyo Bay. Microb. Ecol., 3, 173-191.

Simidu, U., N. Taga, R.R. Colwell and J.R. Schwarz., 1980. Heterotrophic bacterial flora of the seawater from the Nansei Shoto (Ryukyu Retto) area. Bull. Jap. Soc. Sci. Fish., 46, 505-510.

Whipps, J.M., and J.M. Lynch., 1986. The influence of the rhizosphere on crop productivity. In : Advances in microbial ecology, vol. 9 (edited by K.C. Marshall) pp. 187-244. Plenum, New York. (Received September 19, 1989-Accepted November 11, 1989) 